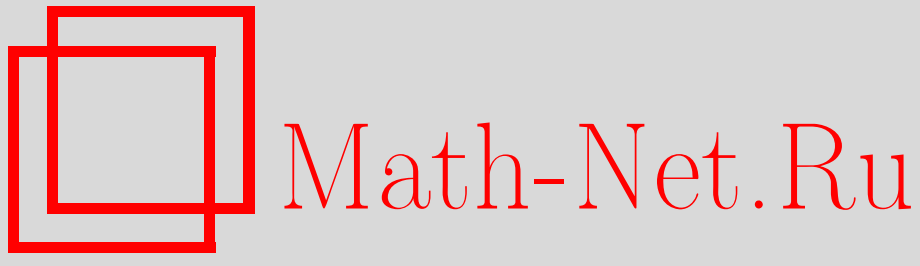

Артин-Брунсвик Н. (некролог), Теория вероятн. и ее примен., 2003, том 48, выпуск 3, 638

DOI: https://doi.org/10.4213/tvp281

Использование Общероссийского математического портала MathNet.Ru подразумевает, что вы прочитали и согласны с пользовательским соглашением

http://www.mathnet.ru/rus/agreement

Параметры загрузки:

IP : 54.198 .67 .100

26 апреля 2023 г., 05:22:46

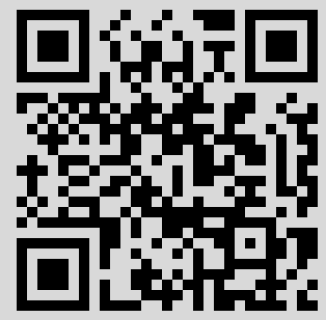




\section{Om Pедколлегии}

Журнал «Теория вероятностей и ее применения» очень быстро после выхода первых номеров в 1956 году стал переводиться Обществом прикладной и промыииенной математики CIIA (SIAM) на английский язык. Ваэсную роль в организачии этого перевода на протяжении многих лет играла Наташа Артин-Брунсвик, скончавшаяся 3 февраля 2003 года. В томе 47 вып. 3 английского издания журнала помещен некролог, написанный Л. Ниренбергом. Мы перепечатываем здесь текст этого некролога.

\section{In Memoriam: \\ Natascha Artin Brunswick, Editor Emeritus}

Natascha (Jasny) Artin Brunswick died February 3, 2003, in Princeton, New Jersey, at the age of 93 .

I first met Natascha in 1946 when she joined the group around Richard Courant at New York University. I was a graduate student at the time. In 1948, when the New York University journal Communications on Pure and Applied Mathematics was founded, Natascha became the technical editor, and she continued as editor until 1991. In 1956, when the SIAM journal Theory of Probability and Its Applications was founded, she became the primary translation editor, and she continued in this position until 1999. She did everything by hand, without computers. In addition she taught mathematics and Russian and translated works from French, Russian, and German for several other journals.

Natascha Jasny was born in St. Petersburg, Russia, on June 11, 1909. After the Bolshevik takeover, the family moved south and, in 1922, fled again, settling finally in Hamburg, Germany. There, after finishing high school at age 16, Natascha studied mathematics at the University of Hamburg, taking courses from Emil Artin, whom she married in 1932, and others including von Neumann and Cassirer. In Hamburg, the Artin children Karin and Michael were born; Tom was born later in the United States.

In 1937 Professor Artin was dismissed from the university because of the racial laws, and he and his family were allowed to leave, arriving in the United States in the summer of 1937. In 1938 they moved to Bloomington, Indiana. Natascha, although formally an enemy alien, taught Russian in the U.S. Army Special Training Program and later at the University of Indiana. In 1946 Professor Artin received an appointment at Princeton University, New Jersey, and the family moved there. He and Natascha were divorced in the 1950s, and in 1959 she married Mark Brunswick, the composer and professor of music at City College.

Throughout her long life, Natascha continued to be active, doing volunteer work at the Princeton Museum, travelling, attending concerts and theatre, and entertaining. In recent years she had two exhibitions in Hamburg of her photographs of the city taken in the 1930s. These were discovered and assembled by her son Tom a few years ago. They are now in the permanent collection of the Museum für Kunst und Gewerbe.

Natascha was a very special person, full of warmth, charm, humor, and generosity of spirit. She put people at ease immediately and was a wonderful friend to many. She was also an excellent cook and a most gracious hostess. In addition to her three children, she is survived by seven grandchildren and nine great-grandchildren. 